УДК [347.77/.78:340.134](477)

DOI https://doi.org/10.32837/pyuv.v0i5.927

B. М. Косович

orcid.org/0000-0002-6551-2686

доктор юридичних наук, доцент,

завідувач кафедри теорії та філософії права

Львівського національного університету імені Івана Франка

\title{
ПРОЄКТ ЗАКОНУ УКРАЇНИ «ПРО АВТОРСЬКЕ ПРАВО І СУМІЖНІ ПРАВА»: ЮРИДИКО-ТЕХНІЧНИЙ АНАЛІЗ
}

Розвиток вітчизняної правової системи характеризується надвисокими темпами законотворчої діяльності. Законодавче регулювання поширюється на дедалі нові сфери суспільного життя. Складається враження, що найближчим часом щодо кожного реального чи потенційного об'єкта правовідносин буде прийнято окремий законодавчий акт. За валом удосконалення та розвитку нормативної бази в тіні залишаються нормативноправові акти, що мають важливе значення для розвитку фундаментальних інститутів українського законодавства. Нині серед таких правових документів, з огляду на необхідність виконання Україною своїх зобов'язань перед іноземними партнерами щодо захисту права інтелектуальної власності, на першочергову увагу заслуговує законодавство про авторські права та механізми їх захисту. Саме тому дослідження проєкту Закону України «Про авторське право і суміжні права» (реєстраційний номер 5552-4 від 09.06.2021р.) [1], поданого на розгляд Верховної Ради України, має актуальне наукове та практичне значення.

Проблематика авторського права $є$ предметом всебічного вивчення фахівців у сфері інтелектуальної власності. Свої праці цій тематиці присвятили К.О. Афанасьєва, В.С. Дроб'язко, С.М. Клейменова, А.В. Шабалін, А.С. Штефан, О.С. Яворська та інші. Не обділяють увагою науковці і питання можливостей удосконалення законодавчого регулювання цього інституту права. Водночас, на нашу думку, дослідження новацій у законодавчій регламентації питань авторського права крізь призму нормопроєктної техніки (яка є предметом вивчення загальної теорії права) сприятиме вдосконаленню проєкту Закону України «Про авторське право і суміжні права» (далі Проєкту).

3 цією метою розглянемо Проєкт на відповідність основним вимогам та правилам нормопроєктної техніки.

Виклад основної частини роботи розпочнемо 3 кількох загальних тез стосовно самого Проєкту та нормопроєктної техніки. Створенню Проєкту передувало використання 3 метою юридичного регулювання питань інтелектуальної власності Закону України «Про авторське право і суміжні права», прийнятого Верховною Радою України ще у 1993 р. (це завидна стабільність для українського законодавства). Щоправда, у 2001 р. цей закон набув нової редакції. 09.06.2021 р. Кабінетом Міністрів України внесено на розгляд Верховної Ради України новий проєкт Закону України «Про авторське право і суміжні права». Як зазначається в пояснювальній записці, необхідність прийняття нового закону зумовлена 16 факторами. У Проєкті знайшли відображення механізми вирішення проблем правового регулювання сфери авторського права і суміжних прав. Прийняття проєкту Закону гарантуватиме забезпечення прав власників у сфері авторського права і суміжних прав відповідно до загальноєвропейських стандартів.

Нормопроєктна техніка як складник правотворчої діяльності на законодавчому рівні нині не формалізована. Були спроби закріпити окремі засоби, прийоми та правила нормопроєктної техніки в проєкті Закону України «Про закони і законодавчу діяльність», проєктах Закону України «Про нормативно-правові акти», є ймовірність ïх законодавчої формалізації через прийняття Закону України «Про правотворчу діяльність» (проєкт розгляду якого нині на порядку денному Верховної Ради). Правила юридичного нормотворення нині в основному окреслюються виданими центральними органами виконавчої влади методичними рекомендаціями 3 дотримання вимог та правил нормопроєктної техніки ${ }^{1}$.

Інтерпретація нормопроєктної техніки та перелік її засобів у проєктованих та чинних правових документах у багатьох випадках не уніфіковані. Тому наведемо кілька базових положень, що розкривають зміст нормопроєктної техніки як основи для техніко-юридичної оцінки Проєкту. Підсумовуючи різні підходи, нормопроєктну техніку можна визначити як систему вимог, засобів і правил, що використовуються для створення проєктів нормативно-правових актів.

Нині дедалі більшої підтримки набуває пози-

${ }^{1}$ Див. Методичні рекомендації щодо розроблення проєктів законів та дотримання вимог нормопроєктної техніки, схвалені Постановою колегії Міністерства юстиції України від 21.11.2000 р. № 41. 
ція про доцільність розмежування засобів нормопроєктної техніки на дві групи: тих, що пов'язані зі змістом, та тих, що є основою для форми нормативно-правового акта.

До змістовних належать такі вимоги та засоби: a) загальні вимоги (законність, відповідність нормам моралі, доцільність, обгрунтованість, ефективність, своєчасність, стабільність, економічність, реальність, оптимальність [2, с. 117]); б) логічні вимоги (тотожність, несуперечність, «виключення третього», послідовність викладу тексту нормативно-правового акта, узгодженість, системність, недопустимість дублювання); в) засоби формування змісту (принципи права, правові конструкції, правові дефініції, правові презумпції, правові фікції).

Друга група засобів і правил охоплює: а) правничу мову та юридичну термінологію; б) правила структуризації нормативно-правових актів; в) реквізитні правила.

Відповідність змістовним вимогам нормопроєктної техніки нині зазвичай опосередковано досліджується фахівцями 3 питань інтелектуальної власності. Тому основний акцент у нашій роботі ми зробимо на з'ясуванні рівня відповідності Проєкту формальним вимогам (яким у згаданих законопроєктах та чинних правових актах iз питань нормопроєктної техніки приділяється основна увага). Крім того, пункт 12 «Методичних рекомендацій щодо проведення правової експертизи проєктів нормативно-правових актів», схвалених Постановою колегії Міністерства юстиції України від 21 листопада 2000 р. № 41, встановлює, що здійснення юридико-технічної оцінки проєкту нормативно-правового акта має на меті визначення ступеня його відповідності усталеним правилам побудови та редакційно-лексичного оформлення нормативно-правових актів.

Техніко-юридичний аналіз Проєкту, оперуючи правилами нормопроєктної техніки, для зручності будемо здійснювати відповідно до його структури.

Проєкт, як і багато інших нормативно-правових актів, містить преамбулу, в якій зазначено: «Цей Закон регулює відносини, пов'язані з виникненням (набуттям), охороною, здійсненням та захистом майнових прав суб'єктів авторського права і суміжних прав та особистих немайнових прав, а також відносини, пов'язані з охороною прав особливого роду («sui generis)». На нашу думку, у преамбулі фактично визначено предмет правового регулювання Закону.

Зазвичай у преамбулах нормативно-правових актів зазначається мета, цілі, завдання, причини, передумови тощо їх прийняття. Відповідно до «Методичних рекомендацій щодо розроблення проєктів законів та дотримання вимог нормотворчої техніки» Міністерства юстиції України преамбула дається, якщо є потреба роз'яснити необ- хідність і мету видання закону. Стаття 31 проєкту Закону України «Про правотворчу діяльність» (реєстраційний номер 5707) передбачає, що преамбула - вступна частина закону, в якій можуть визначатися історична передумова прийняття закону, роз'яснюватися мета, обгрунтовуватися необхідність прийняття закону, визначатися основні завдання, які стоять перед ним, тощо. Преамбула закону не може повторювати зміст інших його структурних складників. Наведене дає підстави висловити думку про необхідність корегування преамбули Проєкту.

Стаття 1 Проєкту присвячена визначенню термінів, що використовуються в різних нормах проєкту. На рівні правової доктрини нині вироблено комплекс рекомендацій стосовно: передумов (підстав) для визначення певних термінів; вимог до самих визначень; правил їх розташування в тексті нормативно-правового акта [3, 4]. Є й окремі правила тлумачення термінології правового характеру ${ }^{2}$. Використовуючи наукові напрацювання та правові приписи, розглянемо правильність визначення окремих термінів Проєкту.

Серед позитивів можна зазначити, що в Проєкті надається обґрунтоване визначення спеціальних термінів, наприклад: кабельна ретрансляція (п. 21 ч. 1 ст. 1); камкординг (п. 22 ч. 1 ст. 1); кардшейрінг (п. 23 ч. 1 ст. 1); попурі (п. 34 ч. 1 ст. 1); постачальник послуг хостингу (п. 35 ч. 1 ст. 1); репрографічне відтворення (репродукування) (п. 46 ч. 1 ст. 1); фонограма (п. 60 ч. 1 ст. 1); цифровий контент (п. 63 ч. 1 ст. 1). Правильним, на нашу думку, є вибір розробниками Проєкту «місця розташування» визначень термінів (як відомо, вони можуть даватись на початку тексту, при першому використанні терміна, у примітках), оскільки це полегшує розуміння норм «насичених» цими термінами упродовж усього законопроєкту. Завдання правового глосарію, з якого розпочинається Проєкт, полягає в тому, щоб дати визначення «оперативних» правових термінів, необхідних для подальшого конструювання законодавчих норм.

Водночас ми знаходимо визначення понять i впродовж тексту законопроєкту. Так, у ч. 4 ст. 20 зазначено: «під вилученням розуміється...», «під повторним використанням розуміється...», у ст. 32 вказано, що під терміном «оригінал твору мистецтва» розуміється...». Такий підхід може зумовлювати певну неузгодженість.

\footnotetext{
${ }^{2}$ Наприклад, у Методичних рекомендаціях із підготовки та оформлення проєктів законів України, нормативно-правових актів Президента України, Кабінету Міністрів України, МНС та дотримання правил нормопроєктної техніки, затверджених Наказом МНС від 10 грудня 2007 р. № 851, зазначено, що визначення термінів доцільно давати лише в законопроєктах загального характеру й у тій частині законопроєкту, де цей термін вживається вперше.
} 
Оцінюючи правові дефініції у світлі вимог нормопроєктної техніки, можна висловити певні міркування стосовно можливостей удосконалення окремих визначень. У п. 17 ч. 1 ст. 1 Проєкту надано визначення терміна «ефірне мовлення» «публічне сповіщення шляхом...» ${ }^{3}$. Серед переліку вимог до правових дефініцій [5, с. 215] є і така: формулювання визначень має бути коротким. Визначення терміна «ефірне мовлення» видається надто об'ємним. У ньому фактично закладено визначення ще одного терміна - «закодований сигнал».

У кількох визначеннях не дотримано вимогу, що полягає в тому, що дефініція не має містити терміни, які використовуються в понятті, що визначається. Наприклад: «інформація про управління правами - інформація, в тому числі...» (п. 20 ч. 1 ст. 1); «публічне демонстрування аудіовізуального твору, фільму - публічне одноразове чи багаторазове представлення...» (п. 43 ч. 1 ст. 1).

Серед недоліків дефініцій, які містяться в законопроєктах, виділяють і такий, як визначення термінів, які пізніше в тексті нормативноправового акта не використовуються. Певним чином схожа ситуація простежується і з дефініцією, що пропонується у п. 58: «Установа - центральний орган виконавчої влади, що забезпечує формування та реалізує державну політику у сфері інтелектуальної власності». Термін «установа" ми знаходимо у ст. 4 Проєкту. Практично у всьому проєкті йдеться про центральний орган виконавчої влади, що забезпечує формування та реалізує державну політику у сфері інтелектуальної власності. Крім того, на рівні загальної теорії права установи та органи держави як елементи механізму держави розмежовуються. Установи (як відомо) - це державні організації, що виконують завдання та функцій держави в гуманітарній сфері, органи ж держави є суб'єктами владних повноважень.

В епоху адаптації вітчизняного законодавства до стандартів міжнародного, насамперед європейського права, методологічне значення має ст. 2 Проєкту, в якій наведено перелік нормативно-правових актів, що входять до законодавства України про авторське право і суміжні права. Йдеться про Конституцію України, Цивільний кодекс України, цей Закон (законопроєкт) та інші закони України, пов'язані зі сферою охорони авторського права і суміжних прав.

Як відомо, нині на рівні науки та юридичної практики термін «законодавство» розуміється по-різному. На цьому тлі своєрідним орієнтиром стосовно розуміння законодавства може бути визначення законодавства, надане у ч. 3 ст. 8 проєкту Закону України «Про правотворчу діяль-

\footnotetext{
${ }^{3} 3$ метою недопущення плагіату наводимо лише перші слова аналізованої правової норми.
}

ність»: законодавство України - ієрархічна система нормативно-правових актів та міжнародних договорів України. Така інтерпретація відповідає ст. 9 Конституції України, відповідно до якої чинні міжнародні договори, згода на обов'язковість яких надана Верховною Радою України, $є$ частиною національного законодавства України.

Аналіз показує, що норми Проєкту базуються на засадах міжнародного права. Зокрема, в пояснювальній записці до Проєкту зазначено, що нині сфера авторського права і суміжних прав потребує вдосконалення 3 врахуванням норм європейського законодавства. Чіткі обов'язки 3 імплементації певних положень права ЄС були взяті на себе Україною під час підписання Угоди про асоціацію. Про міжнародні договори України у сфері авторського права йдеться і у самому Проєкті. У ч. 3 ст. 3 вказано, що суб'єктам авторського права і (або) суміжних прав, незалежно від ï громадянства, твори чи об'єкти суміжних прав яких оприлюднені на території іншої держави або не оприлюднені, але знаходяться в об'єктивній формі на території іншої держави, правова охорона надається відповідно до міжнародних договорів України. Ч. 4 цієї статті встановлює, що іноземці та особи без громадянства відповідно до міжнародних договорів чи на основі принципу взаємності мають однакові з громадянами України права, передбачені цим Законом. Ст. 4 Проєкту серед функцій Установи та HOIB у сфері охорони авторського права і суміжних прав передбачає аналіз стану застосування й дотримання національного законодавства і міжнародних договорів у сфері авторського права і суміжних прав.

Наведене дає підстави пропонувати включення до переліку нормативно-правових актів, що входять до законодавства України про авторське право і суміжні права, відповідні міжнародні договори України.

Вивчаючи статті Проєкту, можна зауважити їхню змістовну «насиченість» .

Можливо, саме це й зумовлює виникнення низки питань щодо окремих норм Проєкту.

У ч. 4 ст. 4 Проєкту наведено перелік владних повноважень у сфері охорони авторського права й суміжних прав, делегованих НОIB. Серед них зазначені і такі: здійснення публікацій в офіційному бюлетені з питань охорони авторського права; здійснення міжнародного співробітництва у сфері правової охорони інтелектуальної власності і представлення інтересів України з питань охорони авторського права та суміжних прав у Всесвітній організації інтелектуальної власності та інших міжнародних організаціях відповідно до законодавства; інформування та надання роз'яснень щодо реалізації державної політики у сфері охорони авторського права та суміжних прав. У площині загальної теорії права, коли йдеться 
про владні повноваження, йдеться насамперед про право встановлювати загальнообов'язкові правила поведінки та приймати нормативно-правові акти. У переліку наведених повноважень НОIB такого немає. Це радше організаційно-розпорядчі повноваження. До того ж не зовсім зрозуміло, чим ці повноваження за змістом відрізняються від наведених у ч. 5 цієї ж статті функцій HOIB?

У ч. 6 аналізованої статті вказано, що НОIB діє на підставі цього Закону, інших законів, актів центрального органу виконавчої влади, що забезпечує формування та реалізує державну політику у сфері інтелектуальної власності, та статуту, затвердженого центральним органом виконавчої влади, що забезпечує формування та реалізує державну політику у сфері інтелектуальної власності. Виникає питання, про який статут йдеться.

У ч. 8 цієї статті зазначено, що для підготовки рекомендацій із питань, що належать до компетенції НОIB, орган проводить наукові дослідження, залучає експертів та консультантів. Якщо цю статтю брати відособлено, то не зовсім зрозуміло, про який орган йдеться. Ч. 9 закріплює, що НОIВ очолює керівник, який призначається на посаду та звільняється 3 посади центральним органом виконавчої влади, що забезпечує формування та реалізує державну політику у сфері інтелектуальної власності, хоча стаття має назву «Повноваження Установи та НОIВ у сфері охорони авторського права і суміжних прав»; і далі аналогічно по тексту.

Багато статей Проєкту містять по кілька юридичних норм (нормативно-правових приписів), що вимагає їх чіткої структуризації та належного позначення структурних елементів. Констатуючи високий рівень дотримання структурних правил, можна висловити побажання детальнішої нумерації окремих статей Проєкту. Зокрема, це стосується ч. 10 ст. 4, в якій у межах однієї частини (без виділення окремих пунктів, у формі абзаців) об’єднуються приписи, що визначають: представницький склад наглядової ради як наглядового органу HOIB; суб'єкта його затвердження; те, що члени наглядової ради виконують свої обов'язки на громадських засадах; порядок обрання голови наглядової ради та його заступників; повноваження наглядової ради; їі права; строк повноважень членів наглядової ради; підстави дострокового припинення повноважень члена наглядової ради; порядок та строки його заміщення; правові засади діяльності наглядової ради; форми роботи наглядової ради; суб'єкта організаційно-матеріального забезпечення діяльності наглядової ради. Для посилання на окремі положення цієї частини статті Проєкту, напевно, треба рахувати абзаци, зокрема, в більшості приписів термін «наглядова рада» подається з малої букви, а в енному абзаці Проєкту сказано: «Формою роботи Наглядової ради є засідання», тобто тут ця інституція починає іменуватися з великої букви.

Ст. 6 Проєкту дає об'ємний перелік об'єктів авторського права - творів у галузі науки, літератури і мистецтва. Загалом наведено 17 позицій. Остання 3 них - інші твори. Оціночне поняття (дослідженню їх використання у Проєкті присвячена окрема робота) «інші твори» робить цей перелік фактично невичерпним, що, з одного боку, є позитивним в умовах бурхливого розвитку людського інтелекту, а 3 іншого боку, ускладнить практичне застосування цієї статті щодо інших об’єктів, прямо не передбачених законом.

Ще серед фундаторів доктрини юридичної техніки існувала дискусія щодо мови права: правнича мова має бути мовою юристів чи мовою, доступною для всіх. Беручи до уваги проєктовані та чинні нормативні приписи, в яких закріплюється вимога точності, ясності та зрозумілості юридичних норм, можна припустити, що сучасна правнича мова повинна мати загальнодоступний характер. У цьому контексті стосовно окремих норм Проєкту виникають певні зауваження, наприклад, щодо закріпленого ч. 6 ст. 40 Проєкту положення: «Розміщення гіперпосилання.... ${ }^{4}$.

Негативною рисою багатьох вітчизняних проєктованих та чинних законодавчих актів є неналежне в них використання Прикінцевих та Перехідних положень. М.О. Теплюк та O.I. Ющик звертають увагу на прийняття великої кількості законів України без перехідних чи кінцевих положень, а відповідно, і без вказівки про їхню чинність та темпоральну дію [6, с. 173]. У проєкті Закону України «Про авторське право і суміжні права» Прикінцеві та Перехідні положення є. У п. 1 цієї складової частини Проєкту вказано на момент набрання чинності, в П. 2 - на втрату чинності іншими законами, в п. 3 - правила застосування строків чинності авторського права та суміжних прав. Якщо позитивно оцінювати зазначені приписи, видається за можливе запропонувати окремі міркування щодо їх вдосконалення. Проєкт Закону України «Про правотворчу діяльність», що відображає сучасні доктринальні та й загалом правові позиції, закріплює такі правила: 1) прикінцеві положення мають встановлювати: порядок набрання чинності актом або його окремими положеннями; перелік нормативноправових актів або їхніх окремих положень, що втрачають чинність; зміни, що вносяться до інших нормативно-правових актів (ст. 33 проєкту); 2) перехідні положення визначають дію нормативно-правового акта, етапи його виконання, порядок регулювання правовідносин, правовий статус суб'єктів правовідносин (ст. 34 проєкту). У проєкті Закону України «Про авторське

\footnotetext{
${ }^{4} 3$ метою недопущення плагіату наводимо лише перші слова аналізованої правової норми.
} 
право і суміжні права» відповідне розмежування та закріплення бажає бути кращим. Крім того, 3 огляду на лавину змін, що пропонується внести у зв'язку із прийняттям Проєкту як закону до інших нормативно-правових актів, кількість положень стосовно темпоральної дії оновлених законодавчих норм необхідно суттєво розширити.

Підсуловуючи, можемо констатувати, що проєкт Закону України «Про авторське право і суміжні права» (реєстраційний номер 5552-4 від 9 червня 2021 р.) є вагомим кроком у розвитку механізму вітчизняного юридичного забезпечення права інтелектуальної власності. Юридико-технічна оцінка Проєкту дає підстави зазначити його високу якість та загалом відповідність вимогам й правилам нормопроєктної техніки. Водночас детальний аналіз норм проєкту дав змогу запропонувати низку рекомендацій стосовно його удосконалення саме крізь призму особливостей нормотворчого інструментарію. Йдеться про використані у Проєкті правові дефініції, загальні вимоги до змісту, його мовні та структурні характеристики. Проведене дослідження є певним внеском у процес науково-експертного оцінювання важливого законопроєкту i може застосовуватись на практиці.

\section{Jimepamypa}

1. Про авторське право i суміжні права : проєкт Закону України від 09 червня 2021 р. № 5552-4 Верховна Рада Украӥни: офіційний вебпортал. URL: http://w1.c1.rada.gov.ua/pls/ zweb2/webproc4_1?pf3511=72188 (дата звернення 12.11.2021).

2. Шутак І.Д. Юридична техніка : навчальний посібник для вищих навчальних закладів. Івано-Франківськ : Коло, 2013. 496 с.

3. Дашковська О. Правові дефініції як різновид нормативних приписів. Вісник Акаделї̈ правових наук України. 2012. № 3 (70). С. 16-23.

4. Подорожна Т.С. Законодавчі дефініції: поняття, структура, функції. Львів : ПАІС, 2009. 196 с.

5. Косович В.М. Удосконалення нормативно-правових актів України: техніко-технологічні аспекти : монографія. Львів : Львівський національний університет імені Івана Франка, 2015. 576 с.

6. Теплюк М.О., Ющик О.І. Введення в дію законів України : питання теорії та практики. Київ : Парламентське видавництво, 2011. 196 с.

\section{Анотація}

Косович В. М. Проєкт Закону України «Про авторське право і суміжні права»: юридико-технічний аналіз. - Стаття.

Стаття присвячена дослідженню можливостей удосконалення механізму законодавчого забезпечення права інтелектуальної власності в Україні 3 огляду на необхідність виконання нашою державою своїх міжнародних зобов'язань щодо захисту авторських прав. Об'єктом аналізу вибрано поданий на розгляд Верховної Ради України проєкт Закону України "Про авторське право і суміжні права" (реєстраційний номер 5552-4 від 9 червня 2021 р.).
Констатовано, що проєкт Закону України «Про авторське право і суміжні права" (Проєкт) є вагомим кроком у розвитку вітчизняної нормативно-правової бази у вказаній сфері відносин. Юридико-технічна оцінка Проєкту дала підстави визначити його високу якість та загалом відповідність вимогам й правилам нормопроєктної техніки. Водночас детальне вивчення норм Проєкту дозволило запропонувати низку рекомендацій щодо його вдосконалення крізь призму особливостей нормотворчого інструментарію. Йдеться про використані в Проєкті правові дефініції, загальні вимоги до змісту, його мовні та структурні характеристики.

Запропоновано внести зміни до преамбули Проєкту, в якій фактично окреслено предмет правового регулювання закону. Преамбула - вступна частина закону, в якій можуть визначатись історичні передумови й обгрунтовуватись необхідність його прийняття, роз'яснюватись мета, окреслюватись основні завдання, які стоять перед ним тощо. Преамбула закону не може повторювати зміст інших його структурних складників.

Вказано на те, що у ст. 1 Проєкту надається обгрунтоване визначення спеціальних термінів, наприклад: кабельна ретрансляція (п. 21 ч. 1 ст. 1); камкординг (п. 22 ч. 1 ст. 1); кардшейрінг (п. 23 ч. 1 ст. 1); попурі (п. 34 ч. 1 ст. 1); постачальник послуг хостингу (п. 35 ч. 1 ст. 1); репрографічне відтворення (репродукування) (п. 46 ч. 1 ст. 1); фонограма (п. 60 ч. 1 ст. 1); цифровий контент (п. 63 ч. 1 ст. 1). Звернено увагу на недотримання в окремих випадках вимоги, згідно з якою формулювання визначень має бути коротким. Наприклад, дефініція терміна «ефірне мовлення» видається надто об'ємною. У ній фактично закладено визначення ще одного терміна - «закодований сигнал». У кількох визначеннях не дотримано правило, за яким дефініція не має містити терміни, які використовуються в понятті, що визначається.

Аргументовано необхідність включення до переліку нормативно-правових актів, що входять до законодавства України про авторське право і суміжні права, вказаного у ст. 2 Проєкту, відповідні міжнародні договори України.

Зазначено високий рівень дотримання у Проєкті структурних правил. Висунено рекомендації щодо детальнішої нумерації окремих статей Проєкту, зокрема ч. 10 ст. 4, в якій у межах однієї частини (без виділення окремих пунктів, у формі абзаців) об'єднуються різні нормативно-правові приписи.

Підсумовано, що вказане дослідження є певним внеском у процес науково-експертного оцінювання важливого законопроєкту і може застосовуватись на практиці.

Ключові слова: авторське право, право інтелектуальної власності, нормопроєктна техніка, вдосконалення проєктованих норм, якість проєкту закону.

\section{Summary}

Kosovych V. M. Draft Law of Ukraine on Copyright and Related Rights: legal and technical analysis. Article.

The article is devoted to the study of the possibilities of improving the mechanism of legislative support of intellectual property law in Ukraine, based on the need to fulfill the international obligations of our state to protect copyright. The object of analysis is the draft Law of Ukraine on Copyright and Related Rights, submitted to the Verkhovna Rada of Ukraine for consideration (registration number 5552-4 dated 09.06.2021). 
It is stated that the draft Law of Ukraine on Copyright and Related Rights (the Draft) is an important step in the development of the domestic legal framework in this area of relations. Legal and technical evaluation of the Draft gave grounds to note its high quality and overall compliance with the requirements of rule-drafting technique. At the same time, a detailed study of the articles of the Draft allowed to offer a number of recommendations for its improvement through the prism of the peculiarities of rule-making tools. These are the legal definitions used in the Project, the general requirements for the content, its linguistic and structural characteristics.

It is proposed to amend the preamble of the Draft, which in fact outlines the subject of legal regulation of the law. The preamble is the introductory part of the law, which can define the historical preconditions and justify the need for its adoption, explain the purpose, outline the main tasks facing it, and so on. The preamble of the law cannot repeat the content of its other structural components.

It is pointed out that Article 1 of the Draft provides reasonable definitions of special terms, for example: cable retransmission (paragraph 21); camcording (paragraph 22); cardsharing (paragraph 23); potpourri (paragraph 34); hosting service provider (paragraph 35 ); reprographic reproduction (reproduction) (paragraph 46); phonogram (paragraph 60); digital content (paragraph 63). Attention is drawn to some cases of noncompliance with the requirement that the wording of definitions should be short. For example, the definition of the term «broadcasting» seems too broad. In fact, it defines another term - «encoded signal». Several definitions do not follow the rule that the definition should not contain terms used in the defined term.

The necessity of inclusion of the relevant international agreements of Ukraine in the list of normative legal acts, forming the legislation of Ukraine on copyright and related rights, specified in Art. 2 of the Draft, is justified.

A high level of compliance with structural rules in the Draft was noted. Recommendations for more detailed numbering of individual articles of the Project, in particular, Part 10 of Art. 4, which combines different regulations within one part (without highlighting individual items, in the form of paragraphs), are proposed.

It is concluded that this study is a contribution to the process of scientific and expert evaluation of an important bill and can be used in practice.

Key words: copyright, intellectual property law, ruledrafting technique, improvement of projected norms, quality of draft law. 